\title{
Influence of Time of Harvesting on the some Mechanical Properties of Fagus sylvatica L. wood as a Construction Material
}

\author{
Vasiliki Dimou $^{1, *}$ and Dimitrios N. Kaziolas ${ }^{2}$ \\ ${ }^{1}$ Department of Forestry and Management of the Environment and Natural Resources, \\ Democritus University of Thrace, Laboratory of Forest Technology, Pandazidou 193, Orestiada, PC 68200, Greece \\ ${ }^{2}$ Department of Forestry and Natural Environment, Hellenic International University, Drama, Greece
}

Received 30 October 2020; Accepted 16 December 2020

\begin{abstract}
The aim of the present study is to investigate the influence of time of stay (pending) of beech (Fagus sylvatica) wood in a forest, after the harvesting, on its resistance to axial compression and to bending. Specifically, specimens of Fagus sylvatica L. wood that have been obtained from logs which were harvested in three different seasons of a year, namely, in July 2017, November 2017 and May 2018 respectively, in the forest of Elatia-Greece, were studied, in order the different period of time of stay (pending) of the experimental surfaces in forest to be ensured. The logs remained in the forest in order to determine if they were affected by fungi or insects. The placement of the experimental surfaces of Fagus sylvatica tree of each harvesting season was made on skid road and on the stand for four months for the first harvesting season, seven months for the second and other four months for the last one. One hundred and twenty laboratory measurements in axial compression and one hundred and twenty measurements in bending (modulus of rupture) for each harvesting season took place. Totally, two hundred and forty laboratory measurements in axial compression and bending proved that there is not any variation on mechanical properties of beech (Fagus sylvatica) wood as a construction material in relation to the logging season.
\end{abstract}

Keywords: Mechanical Properties, Axial Compression, Bending, Harvesting

\section{Introduction}

The continuous decline in softwoods stocks in European forests due to its increasing use in the construction sector will probably lead to a reduction in the supply of softwood as a construction material in the future. Simultaneously, there is an increase hardwoods stocks, such as European beech (Fagus sylvatica L.). At the same time, research is increasingly focused on European beech as it is found that mixtures of European beech and fir forests (Abies alba) in the face of climate change create more resistant forests to drought [1]. In forestry in general, adaptation of mixed clusters in view of the uncertainty of global climate change is considered one of the most important approaches [2]. In this context, coniferous monocultures will become less and less preferred in the future, and broadleafs such as beech will come to the fore. In the northern part of the United Kingdom it is likely that due to climate change this may contribute to increased beech productivity [3]. Moreover, the favorable mechanical properties of beech wood due to its higher density will make possible to exploit this resource as a possible alternative to the lack of softwoods $[1,4]$. European beech (Fagus sylvatica L.) is the most abundant hardwood species in central Europe with standing stocks of $635 \mathrm{M} \mathrm{m}^{3}$ [5] and $263 \mathrm{M} \mathrm{m}^{3}$ in France [6]. In the United Kingdom the hardwood industry is very limited despite the fact that half of the broadleaf forest beech represents about $7 \%$ of this area [7]. Bernasconi [8], pointed out that high mechanical

*E-mail address: vdimou@fmenr.duth.gr

ISSN: 1791-2377@ 2020 School of Science, IHU. All rights reserved. doi:10.25103/jestr.136.08 strength of beech wood is a positive feature for the production of glulam. However, he mentioned the limited availability of strength-graded beech lamellas for glulam production. The latter can be considered as a factor that prevents the use of beech wood. Ridley-Ellis [9] mentions in his work that beech wood has many historical uses, but its exploitation is still insufficient in the modern wood products industry. Moreover, Breinig et al. [4], referred to the steady decline in softwood stocks, and in particular to medium dimension prune, due to the increasing use of timber in the construction sector. Skarvelis et al. [10] also mention that Beech wood is one of the major commercial hardwood species in southeastern Europe. The suitability of beech timber according to Aicher and Ohnesorge [11] for the manufacturing of glulam beams has been investigated since the 1960s and after 2000 different aspects have been studied, such as lamella grading, finger jointing, bonding and the influence of red-heart discoloration.

Beech wood has a significant economic importance for Greece, along with spruce, pine and oak species. Beech is mainly used as round wood and fuel wood (firewood). Beech timber is used as sawn timber for furniture production, but it is also used for fuel wood, boxes, benches, pallets, toys and wooden frames (particle boards, fiber boards) in the Greek market [10] .

In Greece, the traditional logging, takes place in spring or in early summer, depending on weather conditions of the year, as for example logging can only occur after the snow melts. As a result, logged wood remains in the forest ecosystem because loggings occur in the summer months, at a time when it usually favors its infection of the timber lying 
in the forest before to be sold. It is therefore easy to understand the economic consequences of the wood losing much of its value in a short .time after logging, even though it took the trees several decades to reach a marketable size [12].

The present paper aims to investigate the impact of time of stay of beech wood in the forest, in relation to logging season, before its sale and the possible effects on its mechanical properties. This is the second part of an experimental study. In the first part, the effect of blue stain taking into account the time of stay in forest of softwood specimens and especially Picea excelsa and Pinus sylvestris specimens were examined [13].

\section{Methodology}

The conduction of this research included the use of wooden specimens coming from the trees of forest beech (Fagus sylvatica) that were harvested in the forest "Elatia" of the Prefecture of Drama-Greece at an altitude of about 1500 $1580 \mathrm{~m}$.

In order to determine if there is any relation between the time of stay of beech wood specimens in the forest and their mechanical strength, mechanical properties such as axial compression and bending were measured.

\subsection{Preparation of wooden specimens in the forest}

The specimens came from trees that were harvested in three different seasons of the year, namely in July 2017, in November 2017 and in May 2018, in order the different period of stay in forest of beech wood to be ensured. Two trees were harvested in each time, where two experimental surfaces consist of 4 logs of $1 \mathrm{~m}$ length and relatively small differences in stem diameter and cortical thickness came from each tree. The placement of the experimental surfaces was made on skin road and in the stand. In all cases, the lower part of the trunk of the tree of length about $1.00-1.50 \mathrm{~m}$ was not used in order to ensure more uniform material (this part has a larger diameter). A total of 6 felling trees ( 2 in each felling season) were harvested. Six experimental surfaces were created (2 experimental surfaces in each felling season). Each experimental surface consisted of 4 logs and $24 \operatorname{logs}$ were formed (Table 1).

The $\operatorname{logs}$ of $1^{\text {st }}, 2^{\text {nd }}$ and $3^{\text {rd }}$ felling season remained in the forest for four months (from July to November), 7 months (from November to May) and four months (from May to August) respectively. At the end of each month a check took place and the transverse surfaces of the logs were photographed in order their blue-stain infestation to be monitored.

Table 1. Characteristics of experimental logs. Log groups: Fagus sylvatica on skidroad, Fagus sylvatica in stand, Treatment: 01, 02, 03, 04: number of logs in a single group, Mean diameter of each log Table 2

\begin{tabular}{l|l|c|l|l}
\hline Group & Treatment & $\begin{array}{l}\mathbf{1}^{\text {st }} \text { felling } \\
\text { July '17 }\end{array}$ & $\begin{array}{l}\mathbf{2}^{\text {nd }} \text { felling } \\
\text { Novemb. } \\
\text { '17 }\end{array}$ & $\begin{array}{l}\mathbf{3}^{\text {rd }} \\
\text { felling } \\
\text { June'18 }\end{array}$ \\
\hline $\begin{array}{l}\text { Fagus } \\
\text { sylvatica }\end{array}$ & $\begin{array}{l}\text { Pending } \\
\text { period }\end{array}$ & $\begin{array}{l}\text { Jouli- } \\
\text { Nov. }\end{array}$ & Nov.-May & $\begin{array}{l}\text { May- } \\
\text { Aug. }\end{array}$ \\
\hline & & $\begin{array}{c}\text { Mean } \\
\text { diameter }\end{array}$ & $\begin{array}{c}\text { Mean } \\
\text { diameter }\end{array}$ & $\begin{array}{l}\text { Mean } \\
\text { diameter }\end{array}$ \\
\hline & 01 & 30 & 21 & 27 \\
Skidroad & 02 & 29 & 30 & 26 \\
\hline
\end{tabular}

\begin{tabular}{|c|c|c|c|c|}
\hline & $\begin{array}{l}03 \\
04 \\
\end{array}$ & $\begin{array}{l}31 \\
27 \\
\end{array}$ & $\begin{array}{l}23 \\
24 \\
\end{array}$ & $\begin{array}{l}25 \\
24 \\
\end{array}$ \\
\hline Stand & $\begin{array}{l}01 \\
02 \\
03 \\
04\end{array}$ & $\begin{array}{l}25 \\
27 \\
24 \\
23\end{array}$ & $\begin{array}{l}20 \\
21 \\
26 \\
25\end{array}$ & $\begin{array}{l}26 \\
28 \\
30 \\
32\end{array}$ \\
\hline
\end{tabular}

Table 2. Stem breast diameter of trees

\begin{tabular}{c|c}
\hline Logging & Breast Stem diameter \\
\hline $1^{\text {st }}$ skid road & 32 \\
$1^{\text {st }}$ stand & 27 \\
$2^{\text {nd }}$ skid road & 30 \\
$2^{\text {nd }}$ stand & 26 \\
$3^{\text {rd }}$ skid road & 28 \\
$3^{\text {rd }}$ stand & 32 \\
\hline
\end{tabular}

\subsection{Preparation of wooden specimens for the laboratory} measurements

Forty specimens for each felling season were used for the laboratory measurements of the strength to axial compression and bending (totally 80 measurements per felling season). The total number of specimens was eighty per each felling season.

The mean laboratory value (MLV) of strengths cannot be used in practice, due to the variability of wood as a material, to the effect of duration of loading, to the possibility of accidental overloading and to the experience from practice [14]. Therefore, it is necessary the reduction of the mean laboratory value of strengths. The latter is achieved though the calculation of typical strength (TS) applying the following relation [14]:

Typical Strength $(\mathrm{TS})=\frac{M L V-2.33 \cdot \text { stan dard deviation }}{2.5}\left(\mathrm{~N} / \mathrm{mm}^{2}\right)(1)$

Fig. 1 depicts one of the logs of each logging season. We can notice for the $1^{\text {st }} \operatorname{logging}$, the $\log$ on the left side immediately after cutting and next, the same log after four months (the same happens for the $3^{\text {rd }}$ logging), while for the $2^{\text {nd }}$ logging the right log after seven months is depicted.

Table 3 depicts the mechanical properties of wooden specimens that were measured as well as the dimensions of the specimens according to DIN EN 52185, DIN EN 52186, while the laboratory setup of the measurements is depicted in Fig. 2 and 3.

Table 3. Mechanical properties, number and dimension of specimens according to standards DIN EN 52185 (1976), DIN EN 52186 (1978)

\begin{tabular}{l|c|c|c}
\hline $\begin{array}{l}\text { Mechanical } \\
\text { properties }\end{array}$ & $\begin{array}{c}\text { Number of } \\
\text { specimens }\end{array}$ & $\begin{array}{c}\text { Dimensions } \\
\text { of } \\
\text { speciments } \\
(\mathbf{m m})\end{array}$ & Standars \\
\hline $\begin{array}{l}\text { Axial } \\
\text { compression } \\
-M O R\end{array}$ & 40 & $40 \times 20 \times 20$ & DIN EN \\
$\left({\left.\mathrm{N} / \mathrm{mm}^{2}\right)}^{2}\right.$ & & $300 \times 20 \times 20$ & 52185 \\
$\begin{array}{l}\text { Bending } \\
\text { strength } \\
\left(\mathrm{N} / \mathrm{mm}^{2}\right)\end{array}$ & 40 & $\begin{array}{c}\text { DIN EN } \\
52186\end{array}$ & \\
\hline
\end{tabular}



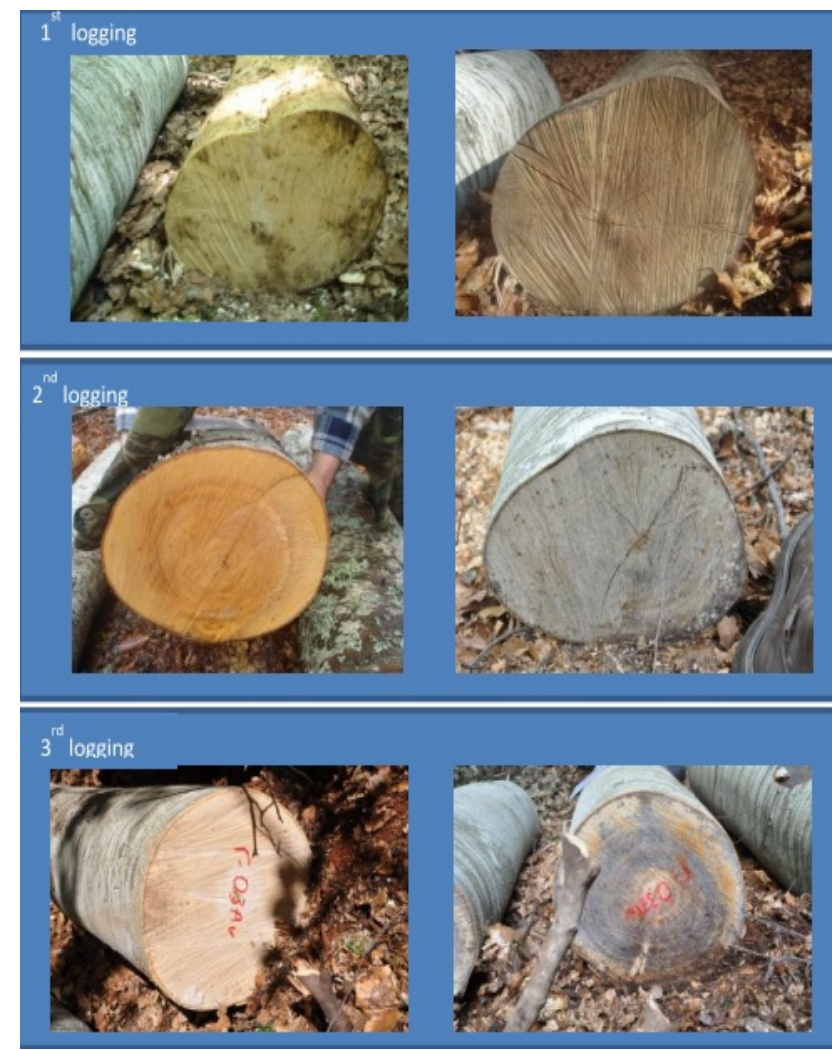

Fig. 1. Photographs showing the beginning and the end for each logging season of the pending period

\section{Results and Discussion}

No infestation by blue-stain or fungi was noticed in all experimental surfaces of the three logging seasons. The latter happens for the whole stay of the experimental surfaces of the three felling seasons in the forest (both in the stand and in the skid road). On the contrary, on the softwood specimens (Picea excelsa and Pinus sylvestris) that were examined by Dimou [13] and remained for the same period in the forest, there was a relatively large deterioration during the 1st and 3rd felling season (mainly of Scots pine), while in the 2nd felling season there was no spread of blue -stain.

\subsection{Experimental results of axial compression and bending}

The results of the laboratory measurements are included in Fig. 2 and 3 giving the maximum axial compression and bending (modulus of rupture). The moisture of the samples was $12 \%$. The results of the mean values of measurements of the resistance to axial compression and bending for the specimens of and for each logging season are depicted in Tab. 5. There seems to be no difference in the results of both axial compression and bending strength between the specimens obtained from the three different logging seasons. The mean axial compression for the three loggings is 71.77 $\mathrm{N} / \mathrm{mm}^{2}$ (Tab. 5) and it is higher than the corresponding values that other researchers resulted, namely $55.43 \mathrm{~N} / \mathrm{mm}^{2}$ (Forestry Facts and Figures 2018) and $54.20 \mathrm{~N} / \mathrm{mm}^{2}$ [15]. The mean bending strength for the three loggings is $124.78 \mathrm{~N} / \mathrm{mm}^{2}$ and it is quite close to the corresponding value of beech wood of central Europe origin (127 N/mm2) [16], while the corresponding value of beech wood of French origin is $111 \mathrm{~N} / \mathrm{mm}^{2}$. Lower bending strength values equal to $104 \mathrm{~N} / \mathrm{mm}^{2}$ and $105.49 \mathrm{~N} / \mathrm{mm}^{2}$ were found in corresponding work by Yilgor et al. [15] and Skarvelis et al. [10] respectively. The differences in the values of mechanical properties between the Greek Fagus sylvatica compared to the Central European Fagus sylvatica are justified by their different origins. Brüchert et al. [17] report in their study, that mechanical strength is influenced by many factors, such as trunk dimensions, crown structure and microenvironment. The mechanical properties depend also on the width of the annular rings where there is an optimal annular ring width [18]. The above mentioned may justify the higher mechanical strength values that arise in the present study in comparison with those found in the literature.

According to classification of Fengel et al. [19], the mechanical resistance to axial compression and bending of beech wood specimens for all the loggings three casts belongs to the "high" rating (Tab. 4).

Table 4. Classification of Axial compression and Bending Strength of all wood species (Fengel et al. 1984)

\begin{tabular}{|c|c|c|}
\hline $\begin{array}{c}\text { Classification } \\
\text { of mechanical } \\
\text { properties }\end{array}$ & $\begin{array}{c}\text { Axial compression } \\
\left(\mathbf{N} / \mathbf{m m}^{2}\right)\end{array}$ & $\begin{array}{l}\text { Bending Strength } \\
\left(\mathrm{N} / \mathbf{m m}^{2}\right)\end{array}$ \\
\hline Very low & $<20$ & $<50$ \\
\hline Low & $20-35$ & $50-85$ \\
\hline Medium & $35-55$ & $85-120$ \\
\hline High & $55-85$ & $120-175$ \\
\hline Very high & $>85$ & $>175$ \\
\hline
\end{tabular}

Table 5. MLVs of mechanical properties of 40 specimens/tree/logging (total specimens 240)

\begin{tabular}{|c|c|c|}
\hline 1 & $\begin{array}{l}\text { Axial } \\
\text { compression } \\
\left(\mathbf{N} / \mathbf{m m}^{2}\right)\end{array}$ & $\begin{array}{l}\text { Bending strength } \\
-\operatorname{MOR}\left(\mathbf{N} / \mathbf{m m}^{2}\right)\end{array}$ \\
\hline & Fagus sylvatica & Fagus sylvatica \\
\hline $\begin{array}{l}1^{\text {st }} \\
\text { logging }\end{array}$ & $72.36(3.6)^{*}$ & $122.04(12.47)$ \\
\hline $\begin{array}{l}2^{\text {nt }} \\
\text { logging }\end{array}$ & $71.56(3.2)$ & $120.80(11.80)$ \\
\hline $\begin{array}{l}3^{\text {rd }} \\
\text { logging }\end{array}$ & $71.41(3.2)$ & $131.50(15.82)$ \\
\hline
\end{tabular}

*standard deviation

Total measurements: 240

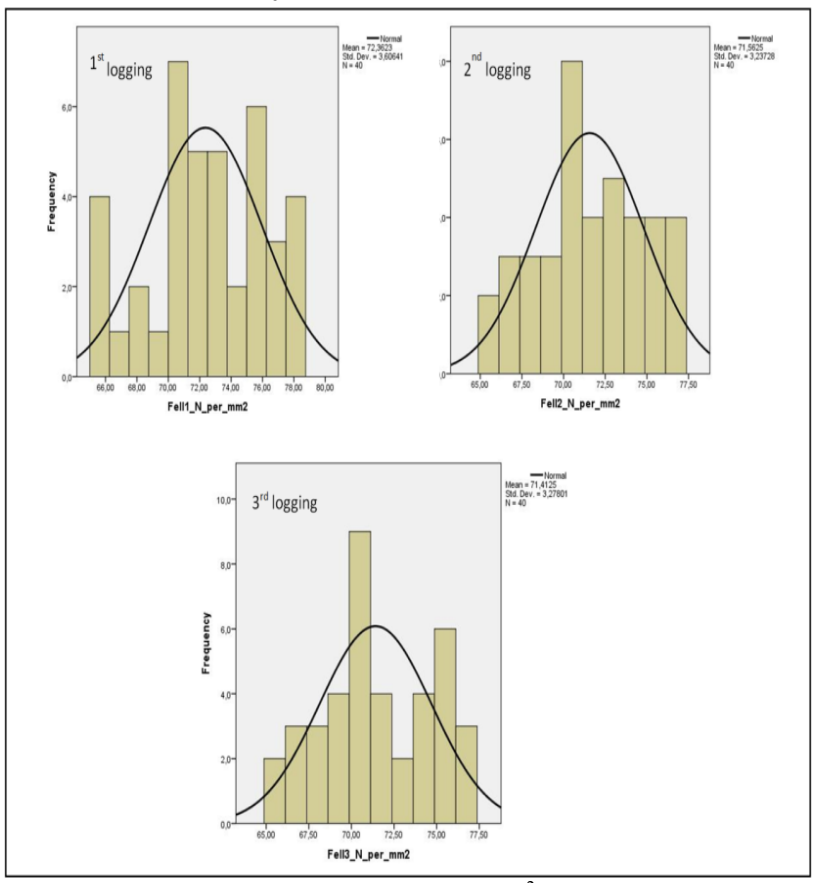

Fig. 2 Maximum axial compression $\left(\mathrm{N} / \mathrm{mm}^{2}\right)$ for the specimens of Fagus sylvatica for each logging season 


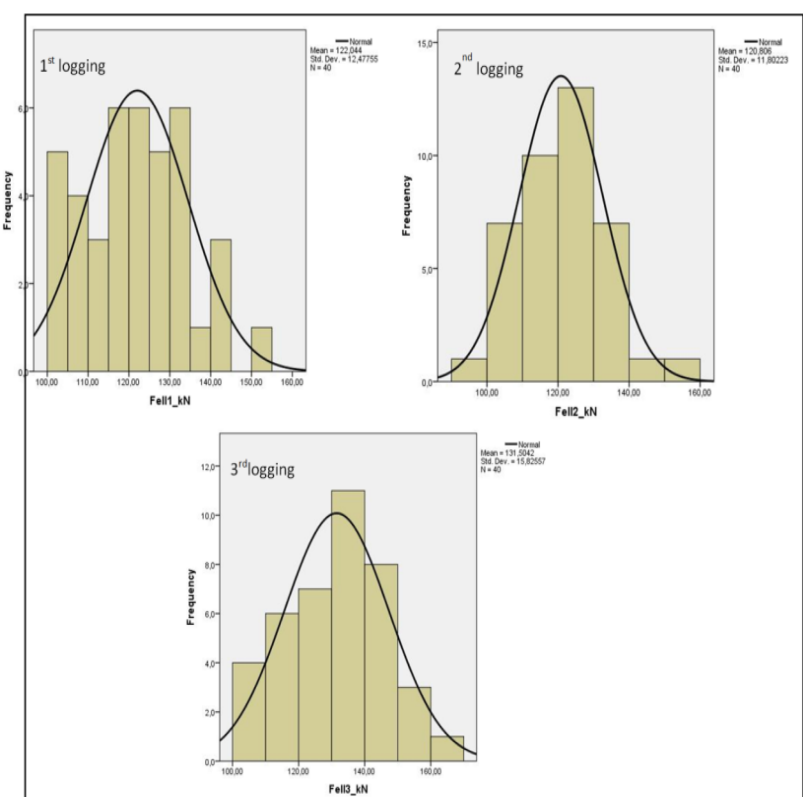

Fig. 3. Maximum bending strength $\left(\mathrm{N} / \mathrm{mm}^{2}\right)$ for the specimens of Fagus sylvatica for each logging season

\subsection{Classification}

The calculation of the value of typical strength according to relation (1), gives values that is approximately equal to $1 / 3$ of the mean laboratory value (Tab. 6). Table 7 depicts the classification of hardwoods species according to the Hellenic Body for Standardisation (ELOT) and Euro code 5 (EN 338) [20]. Taking into account the typical strengths, the classification of woods of Fagus sylvatica for each logging is depicted in Tab. 8, according to the Hellenic Body for Standardisation (ELOT) and Euro code 5 (EN 338) [20]. We can observe that the Fagus sylvatica is classified in class C35 for all loggings and for both axial compression and bending strength. These results are in line with the results of other beech sorting operations in Germany where according to the Euro code 5 (EN 338) [20] it is classified in ratings $\mathrm{C} 40$ and $\mathrm{C} 35$ [9]. We can also notice that there is no difference in mechanical properties of the beech between the three loggings for both axial compression and bending strength. It was observed that beech had no blue-stain for a time period of 4 months for the $1^{\text {st }}$ and $3^{\text {rd }}$ logging and 7 months respectively for the $2^{\text {nd }}$ logging. Both axial compressive strength parallel to the grain bending strength are not affected. These results are in agreement with the results that came out by a similar experimental effort carried out by Dimou et al. [21] where the axial compression and bending strength of Pinus sylvestris and Picea abies species were not affected significantly by the blue-stain effect.

Table 6. Typical Strength per logging

\begin{tabular}{|c|c|c|}
\hline & $\begin{array}{c}\text { Axial } \\
\text { compression } \\
\left(\mathrm{N} / \mathrm{mm}^{2}\right)\end{array}$ & $\begin{array}{l}\text { Bending strength - } \\
\operatorname{MOR}\left(\mathbf{N} / \mathbf{m m}^{2}\right)\end{array}$ \\
\hline & Fagus sylvatica & Fagus sylvatica \\
\hline $1^{\text {st }}$ logging & 25.58 & 37.19 \\
\hline $2^{\text {nd }}$ logging & 25.60 & 37.32 \\
\hline $3^{\text {rd }}$ logging & 25.50 & 37.85 \\
\hline
\end{tabular}

Table 7. Mechanical properties of axial compression parallel to grain of solid timber and bending (EN 338)

\begin{tabular}{l|l|l|l|l|l|l|l}
\hline \multicolumn{7}{c}{ ELOT EN 338 and EC5 Hardwoods } \\
\hline $\begin{array}{l}\text { Classification } \\
\begin{array}{l}\text { Compression } \\
\text { parallel to } \\
\text { grain (axial } \\
\text { compression) }\end{array}\end{array}$ & $\mathrm{f}_{\mathrm{c}, 0, \mathrm{k}}$ & 23 & 25 & 26 & 29 & 32 & 34 \\
$\begin{array}{l}\text { Bending } \\
\text { strength } \\
\left(\mathrm{N} / \mathrm{mm}^{2}\right)\end{array}$ & $\mathrm{f}_{\mathrm{m}, \mathrm{k}}$ & 30 & 35 & 40 & 50 & 60 & 70 \\
\hline
\end{tabular}

Table 8 Classification per logging applying the mores adverse TS calculation and according to ELOT EN338 and EC5 14

ELOT EN 338 and EC5 Hardwoods

\begin{tabular}{|c|c|c|c|c|c|c|}
\hline Classification & C30 & C35 & $\mathrm{C40}$ & C50 & C60 & C70 \\
\hline $\begin{array}{l}\text { Compression } \\
\text { parallel to } \\
\text { grain (axial } \\
\text { compression) }\end{array}$ & & $\begin{array}{l}1^{\text {st }}+2^{\text {nd }} \\
+3^{\text {rd }} \\
\text { Logg. } \\
\text { season }\end{array}$ & & & & \\
\hline $\begin{array}{l}\text { Bending } \\
\text { strength } \\
\left(\mathrm{N} / \mathrm{mm}^{2}\right)\end{array}$ & & $\begin{array}{l}1^{\text {st }}+2^{\text {nd }} \\
+3^{\text {rd }} \\
\text { Logg. } \\
\text { season }\end{array}$ & & & & \\
\hline
\end{tabular}

\section{Conclusions}

The thorough study of wooden specimens proved that their mechanical properties (e.g. strength to axial compression and bending), are not influenced by the duration of time that wood remains in a forest, having as a direct result that the value of Fagus sylvatica wood as construction material is not changed. The classification of wooden species according to the requirements of Euro code 5 (EN 338) (Eurocode 5 ELOT EN338) is independent of the time of logging, the latter did not happen for Pinus sylvestris and Picea abies species according to Dimou et al. [21].

We can conclude that the logging season and the duration of time that the wooden species remain in a forest do not influence the strength in axial compression and bending of wood. However, changing the logging period from spring-summer to autumn-winter is generally accepted by the researchers for many reasons. In general, the damage that can be caused by off-season harvesting operations is less on both the harvested timber and the residual trees.

In nowadays, about two-thirds of the annual beech timber that is harvested, is used for pulp and paper or as fuel wood and only round wood of highest quality is available for sawn timber production [4] (Breinig et al. 2015). The increased durability of the beech wood, its high stocks and its good mechanical properties increase its use in the building sector, a fact that is desirable and expected.

This is an Open Access article distributed under the terms of the Creative Commons Attribution License

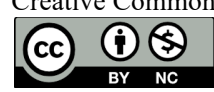

\section{References}

1. A. Julia, J.A. Schwarz, J. Bauhus, "Benefits of Mixtures on Growth Performance of Silver Fir (Abies alba) and European Beech (Fagus sylvatica) Increase With Tree Size Without Reducing Drought
Tolerance", Frontiers in Forests and Global change, (2), DOI: 10.3389/ffgc.2019.00079 (2019). 
2. J. Bauhus, D.I. Forrester, H. Pretzsch, "Mixed-Species Forests: the development of a forest management paradigm, in Mixed-Species Forests". Ecology and Management, (Berlin; Heidelberg: Springer), 1-25. doi: 10.1007/978-3-662-54553-9 1 (2017b).

3. Tree species database, Forest Research, https://www.forestresearch.gov.uk/tools-and-resources/tree-speciesdatabase/beech-be Accessed on 8-2-2020 (2019).

4. L. Breinig, F. Brüchert, A. Haas, U.H. Sauter, "Evaluation of European beech (Fagus sylvatica L.) roundwood for improved production of strength-graded lamellas" https://www.researchgate.net/publication/301548219 Accessed on 9-1-2020 (2015).

5. F. Schmitz, H, Polley, P. Hennig, F. Kroiher, A. Marks, T. Riedel, U. Schmidt, F. Schwitzgebel, T. Stauber, "Der Wald in Deutschland" - Ausgewählte Ergebnisse der dritten Bundeswaldinventur, Bundesministerium für Ernährung und Landwirtschaft (BMEL), Berlin, Germany. (In German) (2014).

6. Anonymous. "Résultats d'inventaire forestier - Résultats standards (campagnes 2009 à 2013) - Tome national version régions administratives". Institut national de l'information géographique et forestière (IGN), Saint-Mandé, France, (In French) (2013).

7. Forestry Facts \& Figures, Forest Research, https://www.forestresearch.gov.uk/tools-andresources/statistics/forestry-statistics/Accessed on 8-2-2020, (2018).

8. A. Bernasconi, "Verleimung von Laubholz für den tragenden Einsatz", Schweizerische Zeitschrift für Forstwesen, 155:533-539 (In German) (2004).

9. D. Ridley-Ellis, "The mechanical and resonance assessment of large clear samples Pro Ligno", online ISSN 2069-7430, Vol. 15 (3) p. 32-39 (2019).

10. M. Skarvelis, G. Mantanis, "Physical and mechanical properties of Beech wood harvested in the Greek", public forests, 58(1) (2013)

11. S. Aicher, D. Ohnesorge, "Shear strength of glued laminated timber made from European beech timber" European Journal of Wood and Wood Products, 69: 143-154. DOI 10.1007/s00107-009-03999 (2011).

12. G. Tsoumis, H. Voulgaridis, "A Study of Blue-stain in Pinus nigra. Prevention of infection in the Forest", Geotechnika, B(1): 3-11pp (1978).

13. V. Dimou, "Harvest-time related blue-stain spread in logs in the Forest of Elatia, Greece", Wood Research, 57(2): 241-250 (2012).

14. H. Voulgarides, "Properties and Wood Technology", Lecture Notes, Thessaloniki (1988).

15. N. Yilgor, O. Unsal, S.N. Kartal, "Physical, mechanical and chemical properties of steamed beech wood, Forest Products Journal, 51(11/12): 89-93 (2001).

16. E. Pöhler, R. Klingner, T. Künniger, "Beech (Fagus sylvatica L.): Technological properties, adhesion behaviour and colour stability with and without coatings of the red heartwood", Ann. For.Sci., 63: 129-137 (2006).

17. F. Brüchert, G. Becker, T. Speck, "The mechanics of Norway Spruce [Picea abies (L.) Karst]: mechanical properties of standing trees from different thinning regime", Forest Ecology and Management, 135, 45-62 (2000).

18. M. Aleinikovas, J. Grigaliunas, "Differences of pine (Pinus sylvestris L.) Wood physical and mechanical properties from different forest site types in Lithuania" Baltic Forestry, 12 (1), 9-13 (2006).

19. D. Fengel, G. Wegener, "Wood Chemistry, Ultrastructure, Reactions" pp.613 (1984).

20. Eurocode $\quad 5 \quad$ ELOT $\quad$ (EN 138 . https://www.woodman.gr/el/thetechnical/57-en338 Accessed on 91-2020.

21. Dimou, D.N. Kaziolas, I. Zygomalas, N. Avtzis, "Influence of biotic factors on the mechanical properties of wood, taking into account the time of harvesting", Wood Material Science \& Engineering, Vol. 12, (3): p. 140-148 http://dx.doi.org/10.1080/17480272.2015.1063004 (2017) 